University of Nebraska - Lincoln

DigitalCommons@University of Nebraska - Lincoln

Publications from USDA-ARS / UNL Faculty

U.S. Department of Agriculture: Agricultural

Research Service, Lincoln, Nebraska

2007

Identification of compounds from Etonia rosemary (Conradina etonia)

Brian P. Quinn

United States Department of Agriculture, brian.quinn@ars.usda.gov

Ulrich R. Bernier

University of Florida, ubernier@gainesville.usda.ufl.edu

Matthew M. Booth

University of Florida College of Medicine

Follow this and additional works at: https://digitalcommons.unl.edu/usdaarsfacpub

Part of the Agricultural Science Commons

Quinn, Brian P.; Bernier, Ulrich R.; and Booth, Matthew M., "Identification of compounds from Etonia rosemary (Conradina etonia)" (2007). Publications from USDA-ARS / UNL Faculty. 956.

https://digitalcommons.unl.edu/usdaarsfacpub/956

This Article is brought to you for free and open access by the U.S. Department of Agriculture: Agricultural Research Service, Lincoln, Nebraska at DigitalCommons@University of Nebraska - Lincoln. It has been accepted for inclusion in Publications from USDA-ARS / UNL Faculty by an authorized administrator of DigitalCommons@University of Nebraska - Lincoln. 


\title{
Identification of compounds from Etonia rosemary (Conradina etonia)
}

\author{
Brian P. Quinn ${ }^{\mathrm{a}, *}$, Ulrich R. Bernier ${ }^{\mathrm{a}}$, Matthew M. Booth ${ }^{\mathrm{b}}$ \\ ${ }^{a}$ United States Department of Agriculture, Agricultural Research Service, Center for Medical, \\ Agricultural, and Veterinary Entomology, 1600 SW 23rd Drive, Gainesville, FL 32608, USA \\ ${ }^{\mathrm{b}}$ University of Florida College of Medicine, Department of Anesthesiology, 1600 SW Archer Road, Gainesville, FL 32610, USA
}

Received 16 March 2007; received in revised form 15 May 2007; accepted 16 May 2007

Available online 25 May 2007

\begin{abstract}
Mosquitoes transmit pathogens that result in diseases harmful to human, livestock, and wildlife hosts. Numerous measures can be used to reduce insect-borne disease risk to humans, and one approach is the use of topical repellents to prevent host-seeking arthropods from taking a blood meal. A current emphasis in the development of new repellents is that they be safe. Therefore, natural products sources are increasingly being explored. Compounds from plants of the mint family (Lamiaceae) have been demonstrated to be insect repellents. This study examines compounds from Etonia rosemary (Conradina etonia) to identify compounds for examination as insect repellents. Samples of Etonia rosemary were passively extracted with hexane, dichloromethane, and methanol and analyzed by GC/MS. This extraction method was chosen to eliminate thermal degradation of plant components that can occur during the distillation procedure. Additional headspace volatile compounds from this plant were identified using microscale purge-and-trap GC/MS. A variety of terpenes, terpenic alcohols, ketones, and aldehydes were identified in the extracts with terpenes and short-chained aldehydes detected in greatest abundance.
\end{abstract}

Published by Elsevier B.V.

Keywords: Mosquito repellents; GC/MS; Headspace analysis

\section{Introduction}

Mosquitoes are vectors of pathogens that cause malaria, dengue fever, West Nile Virus (WNV), Rift Valley Fever, and chikungunya, resulting in death and debilitating illnesses in millions of people each year [1]. There are a variety of control measures that can be employed to reduce the disease risk to humans and animals from these insects. Some of these are the use of spatial repellents, pesticides, larvicides, insecticide treated bednets and clothing, and topical repellents. Anthropogenic repellents such as $\mathrm{N}, \mathrm{N}$-diethyl3-methylbenzamide (DEET) and picaridin are commonly used personal protectants to deter mosquitoes from feeding, because they can be efficacious up to $12 \mathrm{~h}$ after application. Usually, natural repellents are effective for a shorter duration, however, some botanically based repellents such as $p$-menthane 3,8-diol (PMD) from the lemon-scented gum tree (Corymbia citriodora) have recently shown strong promise

\footnotetext{
* Corresponding author. Tel.: +1 352374 5723; fax: +1 3523745922.

E-mail address: brian.quinn@ars.usda.gov (B.P. Quinn).
}

as long-lasting products for protection against mosquitoes $[2,3]$.

Plants are used throughout the world in differing ways, and in some instances as insect repellents [4,5]. In some African cultures, plants are burned to create a spatial repellent [6] while in other regions, many plants are distilled down to their essential oils to create topical repellents [7]. These essential oils are mixtures of compounds, with the primary components usually comprised of terpenes, terpenic alcohols, oxides, and ketones $[8,9]$. Most essential oils are only efficacious as repellents for several hours after application [7], so current emphasis is placed on finding compounds and formulations that provide a greater protection duration against mosquito and insect bites $[3,10,11]$.

Plants from the mint family, Lamiaceae, are widely utilized by human culture. Culinary herbs such as basil, thyme, spearmint, oregano, sage, and rosemary belong to this family. Many multi-use essential oils and botanical repellents are derived from plants found in Lamiaceae including the essential oils and crude extracts of the plant Teucrium leucocladum, shown to be good larvicides for Culex pipiens mosquitoes [12], a species known to be a vector of WNV in North America. A recent study of compounds from beautyberry (Callicarpa spp.) 
yielded a number of candidate mosquito repellents [13]. Leaf extracts of Moschosma polystachyum produced the compound octacosane which repels Culex quinquefasicatus another vector of WNV in the USA. [14]. Essential oil from Thymus sp. was found to have insecticidal properties on adult Mediterranean fruit flies (Ceratitis capitata) [15]. Essential oils and methanol extracts from the plant Thymus pectinatus var. pectinatus were found to be natural sources of antimicrobial agents [16].

Catnip (Nepeta cataria) has long been studied for repellent properties. Eisner [17] demonstrated that nepetalactone, a chemical component isolated from catnip, repelled many insects from different families. Peterson et al. [18] reported that $E, Z$-nepetalactone was much more repellent to the German cockroach than the equivalent dose of DEET. A subsequent study by Peterson and Ems-Wilson [19] showed the subterranean termites avoided soil treated with catnip essential oil. Catnip oil was demonstrated to be a superior spatial repellent than DEET against mosquitoes; however, DEET fared better as a topical repellent [20].

Eisner coined the phrase "global prospecting" when describing the quest to discover new pharmaceuticals from natural products [21,22], an approach that also applies to finding new and effective repellents and insecticides. Therefore, the next logical step in prospecting Lamiaceae is to study lesser-known plants from this family and analyze the compounds present in solvent extracts and volatiles to discover potential repellents or insecticides. False rosemary (Conradina spp.), a member of Lamiaceae, is found primarily in scrub habitat and only in the southeastern United States. This genus includes five species of which four are on the United States Fish and Wildlife's federal list of threatened or endangered plant species. Of these five species, Etonia rosemary (Conradina etonia) is the most highly endangered. This small woody shrub exists as a single population in scrub habitat near Florahome, FL, USA and was not even discovered or described until 1990 [23]. This study is the first report of compounds collected in solvent extracts and volatile analysis of this plant.

\section{Materials and methods}

\subsection{Sample collection}

Samples were collected on 25 October 2006 near Florahome, FL, USA. Using bypass pruners, approximately $150 \mathrm{~g}$ of C. etonia were collected (branches with leaves and no flowers or seeds) from individual plants to prevent excessive damage or plant mortality to this endangered species. Samples were stored in a sealed plastic bag and placed in a cooler on ice until extraction or volatile analysis.

\subsection{Sample extraction}

In the laboratory, samples were removed from the cooler and chopped using bypass pruners. Approximately, $25 \mathrm{~g}$ each of sample was weighed into three separate $250-\mathrm{mL}$ beakers. A $150-\mathrm{mL}$ aliquot of methanol, methylene chloride, or hexane was added to a separate beaker. The solvent was allowed to evaporate, which resulted in passive extraction of compounds. Prior to complete evaporation of the solvent ( $\sim 5 \mathrm{~mL}$ remaining in the beaker), the samples were quantitatively transferred to $15-\mathrm{mL}$ class A centrifuge tubes using Pasteur pipettes and further concentrated to $0.5 \mathrm{~mL}$ using an unheated $N$-Evap 111 Nitrogen Evaporator (Organomation Associates, Berlin, MA, USA). During this concentration step, subsequent aliquots of methanol were added to the methanol extract to aid in water elimination. Passive extraction required no addition of heat, unlike distillation extracts, so thermal degradation products are expected to be absent and thus, we expect a more accurate depiction of compounds normally found in Etonia rosemary.

\subsection{Hexane extract analysis}

A $1-\mu \mathrm{L}$ aliquot from the hexane extract was analyzed along with the appropriate solvent blanks using a ThermoFinnigan Trace GC/MS system (Thermo Fisher Scientific, Waltham, MA, USA) equipped with a DB-Waxetr (Agilent, Wilmington, DE, USA) column $(30 \mathrm{~m} \times 0.25 \mathrm{~mm}$ inner diameter and the film thickness was $0.25 \mu \mathrm{m}$ ). The GC oven temperature program consisted of an initial hold at $35^{\circ} \mathrm{C}$ for $6 \mathrm{~min}$, then a ramp at $10^{\circ} \mathrm{C} / \mathrm{min}$ to $240^{\circ} \mathrm{C}$, followed by a final hold for $5 \mathrm{~min}$ at $240^{\circ} \mathrm{C}$. The programmed temperature vaporizing (PTV) injection port was held at $35^{\circ} \mathrm{C}$ and ramped to $240^{\circ} \mathrm{C}$ in splitless mode, the transfer line was set to $260^{\circ} \mathrm{C}$, and the carrier gas was set to a constant flow of $1.2 \mathrm{~mL} / \mathrm{min}$.

\subsection{Dichloromethane and methanol extract analyses}

A 1- $\mu \mathrm{L}$ aliquot from each extract was analyzed along with the appropriate solvent blanks using a ThermoFinnigan DSQ (Thermo Fisher Scientific) equipped with a DB-5 (Agilent) column $(30 \mathrm{~m} \times 0.25 \mathrm{~mm}$ inner diameter and the film thickness was $0.25 \mu \mathrm{m})$. The $\mathrm{GC}$ oven temperature program consisted of an initial hold at $35^{\circ} \mathrm{C}$ for $6 \mathrm{~min}$, then a ramp at $10^{\circ} \mathrm{C} / \mathrm{min}$ to $310^{\circ} \mathrm{C}$, followed by a final hold for $5 \mathrm{~min}$ at $310^{\circ} \mathrm{C}$. The PTV injection port was held at $35^{\circ} \mathrm{C}$ and ramped to $260^{\circ} \mathrm{C}$ in splitless mode, the transfer line was set to $260^{\circ} \mathrm{C}$, and the carrier gas was set to a constant flow of $1.2 \mathrm{~mL} / \mathrm{min}$.

\subsection{Volatile analysis}

A 25-g plant sample was removed from the cooler and transferred to an opened 1-L Tedlar gas sampling bag (SKC, Eighty Four, PA, USA) and subsequently sealed. The bag with the sample was flushed with humidified ultra-high purity nitrogen and followed by two additional stages of flushing and evacuation. The sample bag was then filled with $1 \mathrm{~L}$ of humidified ultra-high purity nitrogen and then placed into a $45^{\circ} \mathrm{C}$ oven for $30 \mathrm{~min}$ before transferring $600 \mathrm{~mL}$ of the headspace contents of the bag to a $600-\mathrm{mL}$ Silonite ${ }^{\mathrm{TM}}$ coated minicanister (Entech Instruments, Simi Valley, CA, USA).

A 50-mL sample was directed at $100 \mathrm{~mL} / \mathrm{min}$ into an Entech 7100A Preconcentrator (Entech Instruments). This instrument uses a 3-trap system to manage both water and carbon dioxide in air samples. The first trap was a glass bead trap that was 
cooled to $-160^{\circ} \mathrm{C}$. The glass bead trap was then warmed to $10^{\circ} \mathrm{C}$, and the sample was transferred to a Tenax trap that was cooled to $-30^{\circ} \mathrm{C}$. The Tenax trap was heated to $180^{\circ} \mathrm{C}$ and the sample was then transferred over 3 min to a fused silica trap that was cooled to $-160^{\circ} \mathrm{C}$. The fused silica trap was then heated rapidly to $100{ }^{\circ} \mathrm{C}$ and the sample was introduced to a $\mathrm{GC}$ system. The GC/MS used for this analysis was a ThermoFinnigan DSQ (Thermo Fisher Scientific) fitted with a $60 \mathrm{~m} \mathrm{DB} 1-\mathrm{MS}$ (Agilent) column (0.32 $\mathrm{mm}$ inner diameter and $1 \mu \mathrm{m}$ film thickness). The GC oven temperature was held at $35^{\circ} \mathrm{C}$ for $4 \mathrm{~min}$ before it was ramped to $290^{\circ} \mathrm{C}$ at $10^{\circ} \mathrm{C} / \mathrm{min}$ and held at $290^{\circ} \mathrm{C}$ for 5 additional min. The transfer line was held at $280^{\circ} \mathrm{C}$ for the duration of the analysis and the MS was set to scan from $\mathrm{m} / \mathrm{z}, 34$ to 280 at a scan rate of $0.1 \mathrm{~s}^{-1}$.

\subsection{Compound identification}

The US National Institute of Standards and Technology (NIST) mass spectral database library (Gaithersburg, MD, USA) was used for all tentative compound identifications. A reverse fit value of 850 was required for compounds to be considered a spectral match although exceptions were made for compounds like acetic acid if they had only a few ions. We did not scan below $m / z, 34$, which lowers fit and reverse fit values when comparing unidentified compounds to the spectral database library. Tentatively identified compounds also had to fit logically with respect to the retention time in the chromatograms.

\section{Results and discussion}

The passive extraction technique used to concentrate and identify compounds from Etonia rosemary is a departure from a heated distillation for isolation of essential oils, because we sought a plant chemical profile that did not contain thermal degradation products. The solvents hexane, dichloromethane, and methanol were chosen to span a wide polarity range, thereby providing a diverse set of possible compounds to detect in the plant extracts. The hexane extract did not separate well on a DB-5 column, clearly exhibited by many unresolved peaks and poor peak shapes. Therefore, to enhance peak shape and provide better resolution of the extract components, we elected to analyze this extract on a DB-Waxetr column. This column provided adequate separation to identify the constituents. The dichloromethane and methanol extracts chromatographed well on the DB-5 column, so additional analyses with other columns of differing polarity were not required to separate extract components.

Compounds in the hexane extract (Table 1) comprised mostly terpenes, terpenic alcohols, terpenic aldehydes and ketones, xylene, dimethylformamide, and hexadecanoic acid. Terpenes, including $p$-cymene in Etonia rosemary, are present in many plant species including other mints such as Monarda spp. [24], Tarchonanthus camphorates [25], and Lantana camara [26]. Terpenic alcohols in the hexane extract included borneol, terpineol, and pinocarveol. Borneol and terpineol were reported as major components in Conradina canescens (this species is now called Conradina brevifolia) [27]. The most abundant com-
Table 1

Organic compounds present in the solvent extracts of Conradina etonia

\begin{tabular}{|c|c|}
\hline Compound name & Found in extract \\
\hline Xylene & Hexane \\
\hline Limonene & All \\
\hline Eucalyptol & Hexane, dcm \\
\hline Cymene & All \\
\hline$p$-Mentha-1,4(8)-diene & Hexane \\
\hline$N, N$-Dimethylformamide & Hexane \\
\hline 5-Isopropyl-2-methylbicyclo[3.1.0]hexan-2-ol & Hexane \\
\hline Camphor & All \\
\hline 3-Pinanone & Hexane, dcm \\
\hline Terpineol & All \\
\hline Linalool & Hexane, methanol \\
\hline 2(10)-Pinen-3-one & Hexane \\
\hline Caryophyllene & Hexane, dcm \\
\hline Thujenal & Hexane \\
\hline Pinocarveol & Hexane \\
\hline Farnesene & Hexane, dcm \\
\hline$p$-Menth-1-en-8-ol & Hexane \\
\hline Borneol & All \\
\hline$p$-Mentha-6,8-dien-2-one & Hexane, methanol \\
\hline 2-Pinen-10-ol & All \\
\hline p-Cymen-8-ol & Hexane, methanol \\
\hline Caryophyllene oxide & All \\
\hline$\alpha, \alpha$-Dimethyl-1-vinyl-o-menth-8-ene-4-methanol & All \\
\hline Hexadecanoic acid & Hexane \\
\hline Tricyclene & $\mathrm{dcm}$ \\
\hline Pinene & $\mathrm{dem}$ \\
\hline 5,5-Dimethyl-2(5H)-furanone & dem \\
\hline Camphene & $\mathrm{dcm}$ \\
\hline Phellandrene & $\mathrm{dcm}$ \\
\hline 1-Octen-3-ol & dem \\
\hline 3-Octanol & dem \\
\hline Ocimene & dem \\
\hline$p$-Menth-1-en-4-ol & $\mathrm{dcm}$ \\
\hline 2-Pinen-4-one & $\mathrm{dcm}$ \\
\hline$p$-Mentha-6,8-dien-2-ol & $\mathrm{dcm}$ \\
\hline 1-Methyl-4-(1-methylethenyl)-1,2-cyclohexanediol & dcm, methanol \\
\hline Eugenol & $\mathrm{dcm}$ \\
\hline Myrtenyl acetate & dcm, methanol \\
\hline Acetic acid & Methanol \\
\hline Fufural & Methanol \\
\hline 3-Furanmethanol & Methanol \\
\hline 2,4-Dihydroxy-2,5-dimethyl-3(2H)-furanone & Methanol \\
\hline 3-Methoxy-3-oxopropanoic acid & Methanol \\
\hline 3,5-Dihydroxy-6-methyl-2,3-dihydro-4H-pyran-4-one & Methanol \\
\hline Mentha-1,8-diene & Methanol \\
\hline 3,4-Dimethyl styrene & Methanol \\
\hline 1,7,7-Trimethylbicyclo[2.2.1]hept-5-en-ol & Methanol \\
\hline 5-hydroxymethyl-2-furaldehyde & Methanol \\
\hline Eudesmol & \\
\hline
\end{tabular}

pound in this extract was camphor, a terpenoid. Eucalyptol and camphor, the most abundant constituents of the hexane extract, were found to be major components of $C$. brevifolia. In the only other study on false rosemary compounds, it was discovered that the terpenes were allelopathic and prevented fire damage because adjacent plants were eliminated or reduced by inhibition of germination [27]. Another example of terpenes with allelopathic action on endemic plant species was reported from Calamintha ashei, another woody mint found in Florida scrub [28]. McCormick et al. [29] in 1993 conducted 


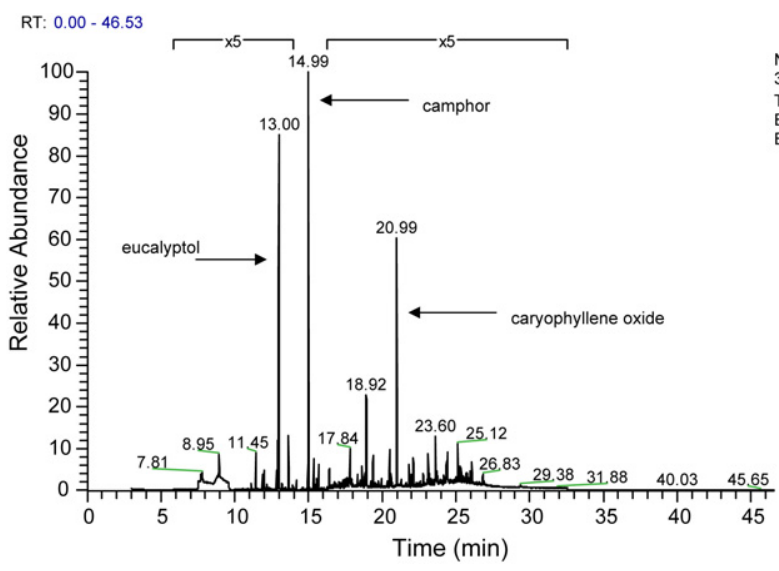

Fig. 1. Chromatogram of dichloromethane extraction of Conradina etonia.

a study on different rare scrub mint species of Dicerandra to see if the chemical signature could help distinguish species. Not only did they find that there were differences in terpene composition for each species, but also that terpene concentrations varied widely over time. This finding was confirmed for Calamintha nepeta when samples were collected over a 6-month period and some major terpenic components such as pugelone exhibited a $40 \%$ change in concentration during certain parts of the year [30]. Finally, location can play a role, such as the case of Hyptis suaveolens, from which terpene concentrations varied widely depending on the geographical area in El Salvador from which it was sampled [31].

The dichloromethane (Table 1, Fig. 1) and the methanol extracts (Table 1) also contained terpenes and terpenic compounds, and as was found for the hexane extract, camphor was the most abundant component. Some of the compounds observed from C. etonia, such as limonene, borneol, and pinene were also found in the Turkish mint plant Stachys oblique [32]. Eugenol and ocimene, present in the dichloromethane extract, occur as the major products of Ocimum suave. When eugenol was chemically removed from the $O$. suave plant extract, repellency to Aedes aegypti mosquitoes dropped from $100 \mathrm{~min}$ of protection time to $0 \mathrm{~min}$, thereby implicating eugenol as the compound that elicited the greatest repellent properties [33]. Linalool, a terpenic alcohol detected in all three solvent extracts is a superior spatial repellent at high concentrations compared to DEET for $A$. aegypti mosquitoes [34].

Volatile components identified from the microscale purgeand-trap GC/MS analysis of C. etonia included shortchained aldehydes such as 2-methylpropanal, methacrolein, 3-methylbutanal, 2-methylbutanal, and pentanal (Table 2, Fig. 2). Some smaller aldehydes have been shown in laboratory bioassays to suppress or inhibit the attraction of mosquitoes to attractants [35]. Terpenes were also detected with camphene being the most abundant in the microscale purge-and-trap analysis. The compound $N, N$-dimethylacetamide was detected, but it was also found in the blank, so it was therefore considered to be a contaminant.
Table 2

Volatile organic compounds from Conradina etonia

\begin{tabular}{lc}
\hline Compound name & $t_{\mathrm{R}}(\mathrm{min})$ \\
\hline 2-Methyl-1-propene & 6.88 \\
Acetone & 7.02 \\
Dimethyl sulfide & 7.81 \\
2-Methylpropanal & 8.70 \\
Methacrolein & 9.01 \\
3-Methylbutanal & 11.44 \\
2-Methylbutanal & 11.65 \\
Pentanal & 12.53 \\
$N, N$-Dimethylacetamide (contaminant) & 15.52 \\
Pinene & 17.62 \\
Tricyclene & 17.71 \\
Camphene & 18.15
\end{tabular}

Essential oils, while widely used throughout the world, have a strong limitation in duration as repellents, and most are effective for less than $4 \mathrm{~h}$ [7]. In contrast, purified botanical active ingredients like PMD provide up to $8 \mathrm{~h}$ of protection from mosquitoes [5]. Tripathi et al. [36] studied the essential oil of Mentha spicta var. viridis and its active ingredient piperitenone oxide as repellents for Anopheles stephensi, a known vector of malaria, and found that piperitenone oxide was five times more effective than the essential oil in repelling this species. These studies indicate that individual botanical compounds may function better as repellents than the corresponding essential oils.

Further studies will be conducted on other plants of Lamiaceae in search of new compounds to be tested as insect repellents and insecticides. Emphasis will be placed on plants with a woody stem like those found in the genera Conradina, Calamintha and Dicerandra, because these rare species produce large concentrations of terpenes as a chemical defense against insects and as an allelopathic weapon to reduce the incidence of fire in adjacent areas, and other intrinsic compounds might yield beneficial compounds for use in protecting humans and livestock from bloodsucking insects.

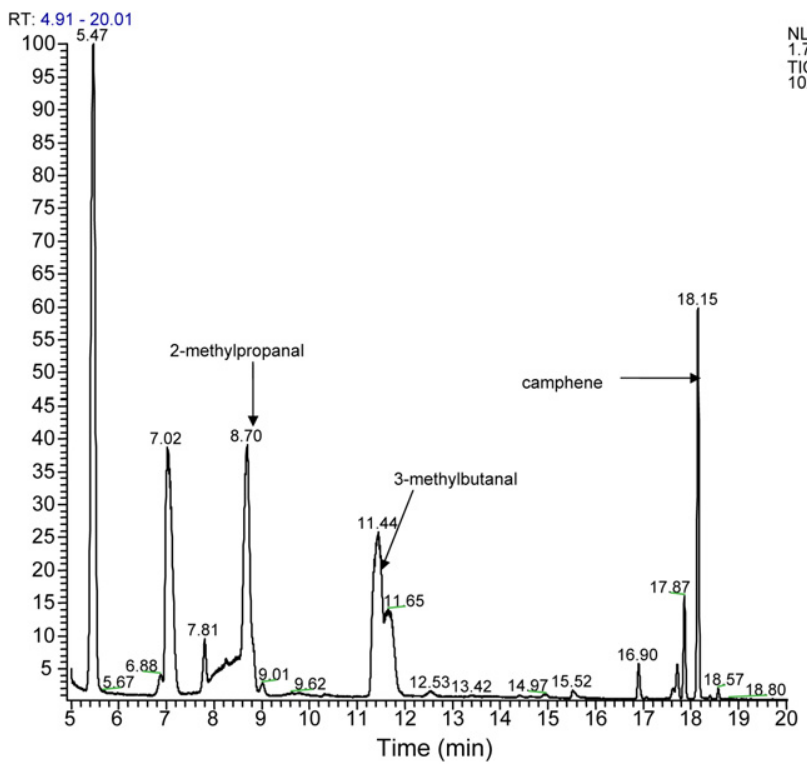

Fig. 2. Chromatogram of volatile components from Conradina etonia. 


\section{Acknowledgments}

The authors thank Mr. Charlie Pederson from the State of Florida Department of Forestry for leading a field trip to collect the plants. This study was partly supported by a grant from the Deployed War-Fighter Protection (DWFP) Research Program, funded by the US Department of Defense through the Armed Forces Pest Management Board (AFPMB).

\section{References}

[1] W.A. Foster, E.D. Walker, in: L.A. Durden, G.R. Mullen (Eds.), Medical and Veterinary Entomology, first ed., Academic Press, San Diego, CA, 2002, p. 204.

[2] C. Peterson, J. Coats, Pestic. Outlook 12 (2001) 154.

[3] T.G.T. Jaenson, S. Garboui, K. Palsson, J. Med. Entomol. 43 (2006) 731.

[4] M.B. Isman, Annu. Rev. Entomol. 51 (2006) 45.

[5] S.J. Moore, A. Lenglet, N. Hill, in: M. Debboun, S.P. Frances, D. Strickman (Eds.), Insect Repellents Principles, Methods, and Uses, first ed., CRC Press, Boca Raton, FL, 2006, p. 275.

[6] K. Palsson, T.G.T. Jaenson, Acta Trop. 72 (1999) 39.

[7] Y. Trongtokit, Y. Rongsriyam, N. Komalamisra, C. Apiwathnasorn, Phytother. Res. 19 (2005) 303.

[8] A.F. Traboulsi, S. El-Haj, M. Tueni, K. Taoubi, N.A. Nader, A. Mrad, Pest Manage. Sci. 61 (2005) 597.

[9] J.P. de Paula, M.R. Gomes-Careiro, F.J.R. Paumgartten, J. Ethnopharm. 88 (2003) 253.

[10] H.C.F. Su, R. Horvat, G. Jilani, J. Agric. Food Chem. 30 (1982) 290.

[11] M.S. Ali, M. Saleem, Z. Ali, V.U. Ahmad, Phytochemistry 55 (2000) 933.

[12] A.M. El-Shazly, K.T. Hussein, Biochem. Syst. Ecol. 32 (2004) 665.

[13] C.L. Cantrell, J.A. Klun, C.T. Bryson, M. Kobaisy, S.O. Duke, J. Agric. Food Chem. 53 (2005) 5948.

[14] S. Rajkumar, A. Jebanesan, J. Ethnopharm. 90 (2004) 87.
[15] G.S. Passino, E. Bazzoni, M.D.L. Moretti, R. Prota, J. Appl. Entomol. 123 (1999) 145

[16] G. Vardar-Unlu, F. Candan, A. Sokmen, D. Daferera, M. Polissiou, M. Sokmen, E. Donmez, B. Tepe, J. Agric. Food Chem. 51 (2003) 63.

[17] T. Eisner, Science 146 (1964) 1318.

[18] C.J. Peterson, L.T. Nemetz, L.M. Jones, J.R. Coats, J. Econ. Entomol. 95 (2002) 377.

[19] C.J. Peterson, J. Ems-Wilson, J. Econ. Entomol. 96 (2003) 1275.

[20] U.R. Bernier, K.D. Furman, D.L. Kline, S.A. Allan, D.R. Barnard, J. Med. Entomol. 42 (2005) 306

[21] T. Eisner, E.A. Beiring, Bioscience 44 (1994) 95.

[22] T. Eisner, Proc. Am. Philos. Soc. 138 (1994) 385.

[23] R. Kral, R.B. McCartney, Sida 14 (1991) 391.

[24] R.W. Scora, Amer. J. Bot. 54 (1967) 446.

[25] M.O. Omolo, D. Okinyo, I.O. Ndiege, W. Lwande, A. Hassanali, Phytochemistry 65 (2004) 2797.

[26] A.J. Sundufu, H. Shoushan, J. Flavour Frag. 19 (2004) 229.

[27] N.H. Fischer, G.B. Williamson, J.D. Weidenhamer, D.R. Richardson, J. Chem. Ecol. 20 (1994) 1355.

[28] J.D. Weidenhamer, M. Menelaou, F.A. Macias, N.H. Fischer, D.R. Richardson, G.B. Williamson, J. Chem. Ecol. 20 (1994) 3345.

[29] K.D. McCormick, M.A. Deyrup, E.S. Menges, S.R. Wallace, J. Meinwald, T. Eisner, Proc. Natl. Acad. Sci. USA 90 (1993) 7701.

[30] N. Baldovini, D. Ristorcelli, F. Tomi, J. Casanova, J. Flavour Frag. 15 (2000) 50.

[31] P. Grassi, M.J. Nunez, K. Varmuza, C. Franz, J. Flavour Frag. 20 (2005) 131.

[32] M. Harmandar, M.E. Duru, A. Fakir, T. Hirata, S. Izumi, J. Flavour Frag. (1997) 211

[33] J.B. Chogo, G. Crank, J. Nat. Prod. 44 (1981) 308.

[34] D.L. Kline, U.R. Bernier, K.H. Posey, D.R. Barnard, J. Med. Entomol. 40 (2003) 463.

[35] U.R. Bernier, D.L. Kline, K.H. Posey, in: M. Debboun, S.P. Frances, D. Strickman (Eds.), Insect Repellents Principles, Methods, and Uses, first ed., CRC Press, Boca Raton, FL, 2006, p. 77.

[36] A.K. Tripathi, V. Prajapati, A. Ahmad, K.K. Aggarwal, S.P.S. Khanuja, J. Med. Entomol. 41 (2004) 691. 